\title{
EFFECT OF NICKEL CONTENT ON DELTA SOLVUS TEMPERATURE AND MECHANICAL PROPERTIES OF ALLOY 718
}

\author{
Richard B. Frank, Christopher G. Roberts, and Jingxian Zhang \\ Carpenter Technology Corporation, R\&D Laboratory \\ 1600 Centre Avenue, Reading, PA, 19601, USA
}

\begin{abstract}
Keywords: Alloy 718, nickel, niobium, solvus, delta phase, Laves phase, mechanical properties,
CALPHAD modeling
\end{abstract}

\begin{abstract}
Knowledge and control of the delta phase $\left(\mathrm{Ni}_{3} \mathrm{Nb}\right)$ solvus temperature is critical to optimize processing and heat treatment of alloy 718 for best mechanical properties. This is the case in aerospace applications where delta phase is used to produce fine grain structures during forging, and in oil-field applications where the delta phase is dissolved during solution treatment. Delta phase solvus is primarily controlled by niobium content. The effect of nickel content on delta phase solvus is not well understood as thermodynamic models and previous experiments have produced conflicting results. The purpose of this study was to confirm the effect of nickel content on delta solvus temperature using experimental heats and to document mechanical properties vs. nickel content. In addition, solvus results were compared with modeling predictions and an improved database was developed to more accurately predict delta phase solvus temperature in alloy 718 .
\end{abstract}

\section{Introduction}

Delta is an orthorhombic phase that is incoherent with the face-centered cubic matrix. Delta phase size, morphology, and distribution dictate whether the phase is beneficial or detrimental to alloy performance. A uniformly-dispersed globular precipitate will facilitate grain refinement while a lathlike or needle morphology will adversely affect stress rupture and fracture toughness properties [1,2].

For aerospace applications, knowledge of the delta solvus temperature is essential for identifying forging and heating temperature practices that incorporate a dispersed delta phase to obtain the desired uniform fine grain structures. For oil-field applications where delta phase is undesirable for fracture toughness, knowledge and control of the solvus temperature is important for determination of super-solvus solution treatment temperatures to fully dissolve delta phase while limiting grain growth.

It is well known that the delta phase solvus is primarily controlled by niobium content [3]; however, niobium content in alloy 718 is typically tightly controlled by industry specifications, either directly or indirectly by the mechanical properties required (niobium controls strength). The effect of nickel content on delta phase solvus is not well understood and thermodynamic models and previous experiments have produced conflicting results. Work by E. Raymond [4] indicates that delta solvus of 718 billet increases with nickel content in the 52-54\% range. Other researchers [5] found no significant effect of nickel, cobalt, and iron levels on delta solvus temperature. Modeling simulations using the databases from Thermotech and CompuTherm 
predict conflicting trends for nickel. Also, both databases predict solvus temperatures significantly higher than the $990-1015^{\circ} \mathrm{C}$ range typically observed in alloy $718[3,6]$.

Computational thermodynamic modeling based on the CALPHAD (CALculation of PHAse Diagrams) approach can be employed to predict the fractions of equilibrium and metastable phases, and their compositions in multi-element systems. Modeling is now routinely used in the metals industry to better understand the physical metallurgy of existing alloys and to facilitate the development of new alloys. While commercially available thermodynamic modeling software, such as Thermo-Calc, Pandat ${ }^{\circledR}$, and JMatPro are becoming increasingly user-friendly, the key to using these predictions effectively is the accuracy of the databases being used. It is important for the users to understand the strengths and limitations of each database so that they can apply the calculation results appropriately to the alloy design and evaluation process.

Currently, there are two major commercial databases available for nickel-base superalloys, NiDATA from Thermotech [7] and PanNickel from CompuTherm [8]. Zhao et al. evaluated the Ni-DATA database by comparing the thermodynamic predictions with experimental observations [9]. Zhao's work showed that the thermodynamic calculations predict the stability of the gamma prime phase reasonably well but the predictions for TCP phases are less satisfactory. A recent paper by Olson et al. indicated that Ni-DATA (version 7) is more favorable compared to PanNickel, because it predicts the volume fraction and composition of gamma prime phase accurately [10]. However, systematic assessment of the databases for delta phase predictions has not been performed.

The objectives of this study were: 1.) to confirm the effect of nickel content on delta solvus temperature using experimental heats; 2.) to document effects on room temperature tensile, Charpy V-notch impact, and stress-rupture properties; and 3.) to assess the thermodynamic databases for delta phase prediction in alloy 718. Niobium variations were also evaluated for comparison.

\section{Experimental Procedure}

\section{Alloy Modeling}

The effects of nickel and niobium contents on delta phase solvus temperature of alloy 718 were studied using the commercial thermodynamic modeling softwares Thermo-Calc and Pandat.

Two databases were employed in this work, Ni-DATA, version 8 (TTNi8) and PanNickel.

\section{Experimental Alloy Processing}

Three nickel levels, within the typical $50-55 \%$ broad range for alloy 718 , were selected for evaluation $(51.5 \%, 53 \%$, and 54.5\%). All compositions are expressed in weight percent. Niobium levels of $5.0 \%, 5.2 \%$, and $5.4 \%$ were also evaluated at the intermediate $53 \%$ nickel level. Five $40-\mathrm{lb}(18-\mathrm{kg})$ laboratory heats were vacuum-induction melted and cast as $100-\mathrm{mm}$ square ingots. The chemical compositions of the heats are listed in Table I.

Pandat@ is a registered U.S. trademark of CompuTherm, LLC. 
Table I. Chemical Compositions (Wt\%) of Alloy 718 Experimental Heats

\begin{tabular}{|c|c|c|c|c|c|c|c|c|c|c|c|c|c|}
\hline Heat & $\mathbf{C}$ & $\mathbf{M n}$ & $\mathbf{S i}$ & $\mathbf{P}$ & $\mathbf{S}$ & $\mathbf{N i}$ & $\mathbf{N b}$ & $\mathbf{C r}$ & $\mathbf{M o}$ & $\mathbf{T i}$ & $\mathbf{A l}$ & $\mathbf{B}$ & $\mathbf{F e}$ \\
\hline 1 & 0.03 & 0.07 & 0.10 & 0.006 & $6 \mathrm{ppm}$ & $\mathbf{5 1 . 5 3}$ & $\mathbf{5 . 1 7}$ & 18.26 & 2.97 & 0.98 & 0.50 & 0.004 & 20.2 \\
\hline 2 & 0.03 & 0.07 & 0.10 & 0.006 & $<5 \mathrm{ppm}$ & $\mathbf{5 3 . 0 5}$ & $\mathbf{5 . 0 0}$ & 18.24 & 2.97 & 0.98 & 0.51 & 0.004 & 18.9 \\
\hline 3 & 0.03 & 0.07 & 0.10 & 0.006 & $6 \mathrm{ppm}$ & $\mathbf{5 3 . 0 8}$ & $\mathbf{5 . 1 8}$ & 18.29 & 2.97 & 0.98 & 0.50 & 0.004 & 18.7 \\
\hline 4 & 0.03 & 0.07 & 0.10 & 0.006 & $6 \mathrm{ppm}$ & $\mathbf{5 3 . 0 4}$ & $\mathbf{5 . 4 2}$ & 18.24 & 2.97 & 0.98 & 0.50 & 0.004 & 18.5 \\
\hline 5 & 0.03 & 0.07 & 0.10 & 0.006 & $<5 \mathrm{ppm}$ & $\mathbf{5 4 . 5 2}$ & $\mathbf{5 . 1 8}$ & 18.26 & 2.97 & 0.98 & 0.50 & 0.004 & 17.3 \\
\hline
\end{tabular}

The ingots were homogenized, soaked at $1120^{\circ} \mathrm{C}\left(2050^{\circ} \mathrm{F}\right)$, and press-forged to $64-\mathrm{mm}$ doubleoctagon bars. After bar turning, the bars were then hot-rolled to $19-\mathrm{mm}$ round bars from $1120^{\circ} \mathrm{C}$ $\left(2050^{\circ} \mathrm{F}\right)$ using hand rolling mills.

To compare response to solution treatment, as-rolled bar samples were treated at temperatures ranging from $925^{\circ} \mathrm{C}$ to $1025^{\circ} \mathrm{C}\left(1700-1875^{\circ} \mathrm{F}\right)$ in increments of $28^{\circ} \mathrm{C}\left(50^{\circ} \mathrm{F}\right)$ for one hour and water quenched. Smaller temperature increments were used in the temperature ranges where recrystallization and delta solution occurred. Hardness and microstructure of longitudinal midradius sections of the solution-treated samples were evaluated. Metallographic specimens were ground and polished using conventional preparation techniques. Samples were swabbed with aqua regia etchant to reveal grain structure and secondary phases.

Solvus and Phase Analysis

Calorimetry was utilized to evaluate melting range and solvus temperatures of the alloys. Disks $(40 \mathrm{mg})$ were electric discharge machined from as-forged and heat-treated samples. A TA Instruments ${ }^{\circledR}$ model Q600 differential thermal analyzer (DTA) was used in this study. Alumina crucibles, argon cover gas with a $100 \mathrm{~mL} / \mathrm{min}$ flow rate, and $20^{\circ} \mathrm{C} / \mathrm{min}$ heating rate were applied to all scans.

The gamma-double-prime $\left(\gamma^{\prime \prime}\right)$ hardener phase solvus was measured using DTA and the solvus temperature corresponds to the peak maximum of the endothermic peak. Metallographic assessment of the delta solvus was performed in place of DTA because the endothermic peaks associated with dissolution of the delta phase are difficult to resolve. The poor resolution is attributed to slow reaction kinetics [11].

Transmission electron microscopy was incorporated for quantification of compositions and verification of phases. Carbon extraction replica specimens were prepared from $925^{\circ} \mathrm{C}$ $\left(1700^{\circ} \mathrm{F}\right) / 1$ hour treated samples from heats \#1 and \#3, which represent the low-nickel and intermediate-nickel contents. A Philips model EM-420T operating at $120 \mathrm{kV}$ provided images, energy dispersive spectrums (EDS), and selected area electron diffraction patterns (SAED) to identify the minor phases.

Mechanical Property Evaluation

For evaluation of mechanical properties, solution and aging heat treatments commonly used for aerospace and oil-field 718 products were applied. The heat treatments were as follows:

Aerospace: $954^{\circ} \mathrm{C}\left(1750^{\circ} \mathrm{F}\right) / 1 \mathrm{~h} / \mathrm{AC}+718^{\circ} \mathrm{C}\left(1325^{\circ} \mathrm{F}\right) / 8 \mathrm{~h} / \mathrm{FC}$ to $621^{\circ} \mathrm{C}\left(1150^{\circ} \mathrm{F}\right) / 8 \mathrm{~h} / \mathrm{AC}$ Oil-Field: $1024^{\circ} \mathrm{C}\left(1875^{\circ} \mathrm{F}\right) / 1 \mathrm{~h} / \mathrm{OQ}+785^{\circ} \mathrm{C}\left(1445^{\circ} \mathrm{F}\right) / 6 \mathrm{~h} / \mathrm{AC}$

TA Instruments $®$ is a registered U.S. trademark of Waters Technologies Corporation 
Heat-treated blanks were machined/ground to 6.35-mm gage diameter tensile and stress-rupture specimens and standard Charpy V-notch impact specimens (10-mm square). Hardness, tensile and impact tests were conducted at room temperature. Stress-rupture tests were conducted at a temperature of $649^{\circ} \mathrm{C}\left(1200^{\circ} \mathrm{F}\right)$ using a load of $758 \mathrm{MPa}(110 \mathrm{ksi})$. Since stress-rupture testing is only relevant for applications above about $538^{\circ} \mathrm{C}\left(1000^{\circ} \mathrm{F}\right)$, only the aerospace-treated samples were evaluated in this test.

\section{Results and Discussion}

Phase Solvus and Microstructure

The microstructures of the hot-rolled bars were consistent among the five heats. A fine ASTM 11-12 grain size was obtained in all cases. The melting range was found to be $1260-1357^{\circ} \mathrm{C}$ $\left(2300-2475^{\circ} \mathrm{F}\right)$. There were no significant differences in melting range within the $51.5-54.5 \%$ nickel and 5.0-5.4\% niobium composition ranges.

Table II contains the solvus temperature data. Figure 1 shows that nickel content had little or no effect on gamma-double-prime $\left(\gamma^{\prime \prime}\right)$ or delta solvus temperatures. Moreover, both solvus temperatures were found to be positively correlated with niobium content as would be expected. The delta solvus temperatures are similar to those documented by others $[3,6]$. The $\gamma^{\prime \prime}$ solvus was observed over the range of $915-926^{\circ} \mathrm{C}\left(1679-1699^{\circ} \mathrm{F}\right)$. Previous DTA investigations have measured $\gamma^{\prime \prime}$ solvus temperatures of $894^{\circ} \mathrm{C}\left(1641^{\circ} \mathrm{F}\right)$ [11] and $877^{\circ} \mathrm{C}\left(1611^{\circ} \mathrm{F}\right)$ [12]. Differences may be related to techniques used to evaluate the thermograms.

Table II. Solvus Temperatures of Alloy 718 Experimental Heats

\begin{tabular}{|c|c|c|c|c|c|}
\hline Nickel & Niobium & \multicolumn{2}{|c|}{ Gamma Double Prime } & \multicolumn{2}{|c|}{ Delta $^{1}$ Phase $^{2}$} \\
\hline (wt\%) & (wt\%) & ${ }^{\circ} \mathrm{C}$ & ${ }^{\circ} \mathrm{F}$ & ${ }^{\circ} \mathrm{C}$ & ${ }^{\circ} \mathrm{F}$ \\
\hline 51.5 & 5.2 & 921 & 1689 & 1002 & 1835 \\
\hline 53.1 & 5.0 & 915 & 1680 & 993 & 1820 \\
\hline 53.1 & 5.2 & 922 & 1691 & 1004 & 1840 \\
\hline 53.0 & 5.4 & 927 & 1700 & 1010 & 1850 \\
\hline 54.5 & 5.2 & 924 & 1695 & 1004 & 1840 \\
\hline
\end{tabular}

1 - determined using DTA

2 - determined using metallography of treated samples 

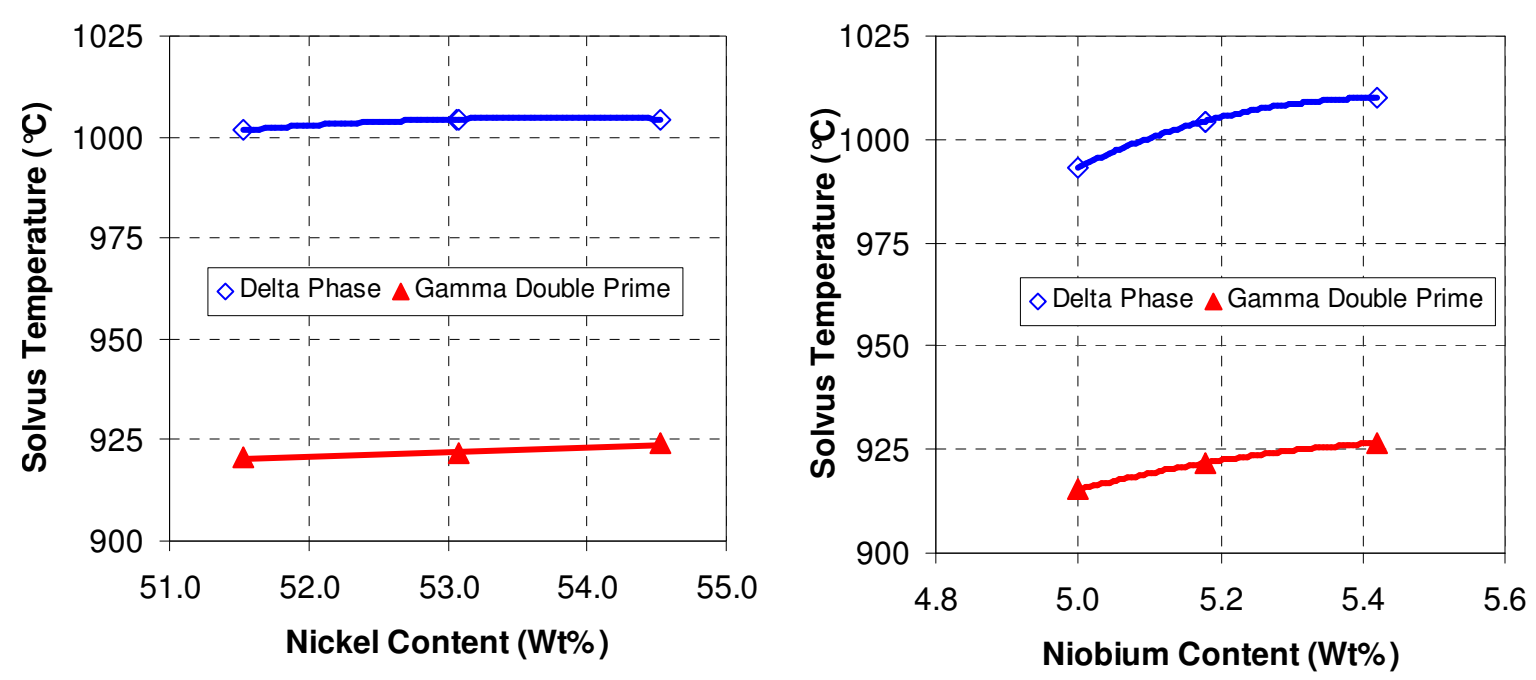

Figure 1. Effect of nickel and niobium contents on solvus temperatures of alloy 718 (determined experimentally using laboratory heats)

No grain growth was observed in specimens that were heat-treated below the delta solvus. The amount of delta phase was greater in samples with higher niobium content. Near the delta solvus temperature, the fraction of delta precipitates on grain boundaries was insufficient and grain coarsening was observed; the resultant microstructures exhibited mixed or duplex grain sizes.

Table III. Alloy 718 Phase Composition Data* (Wt\%)

\begin{tabular}{|c|c|c|c|c|c|c|c|c|c|}
\hline Heat & Phase & $\mathbf{N i}$ & $\mathbf{F e}$ & $\mathbf{C r}$ & $\mathbf{N b}$ & $\mathbf{T i}$ & $\mathbf{A l}$ & Mo & $\mathbf{S i}$ \\
\hline$\# 1(51.5 \% \mathrm{Ni}, 5.2 \% \mathrm{Nb})$ & Delta & 64.2 & 2.6 & 0.8 & 28.8 & 2.1 & 0.1 & 0.9 & 0.2 \\
\hline$"$ & Laves & 28.8 & 15.5 & 13.1 & 26.5 & 0.2 & 0.3 & 13.0 & 1.3 \\
\hline$\# 3(53.1 \% \mathrm{Ni}, 5.2 \% \mathrm{Nb})$ & Delta & 64.7 & 2.8 & 0.7 & 27.5 & 2.0 & 0.2 & 1.0 & 0.9 \\
\hline$"$ & Laves & \multicolumn{1}{|c|}{ Lo Laves detected in this composition } \\
\hline
\end{tabular}

* - Data obtained by EDS of $925^{\circ} \mathrm{C}$ treated samples

Table III lists the compositions of the phases found in heats \#1 and \#3 after treatment at $925^{\circ} \mathrm{C}$ $\left(1700^{\circ} \mathrm{F}\right)$ for 1 hour. Delta phase was confirmed (TEM/SAED) in these heats but was observed in all compositions heat treated below the delta solvus range of $993-1010^{\circ} \mathrm{C}\left(1820-1850^{\circ} \mathrm{F}\right)$. In the low-nickel heat, a few of the precipitates matched the Laves phase crystal structure and exhibited a composition significantly different from the matrix and delta precipitates. Extensive research has addressed the presence of Laves phase in alloy 718 in the as-cast condition $[2,13,14]$. The use of ingot homogenization treatments has been shown to dissolve the Laves phase and reduce the segregation of niobium in alloy 718. Likewise, control of niobium and silicon levels decreases propensity to form Laves. For these reasons, Laves phase is not common in wrought products of commercial alloy 718 in the solution-treated condition. Given that Laves phase was found in heat \#1 and not in heat \#3, this work confirms that a minimum critical nickel content is necessary to achieve a Laves-free microstructure in homogenized wrought products of alloy 718 . 
Modeling of Solvus Temperature

For both Ni-DATA, version 8 (TTNi8) and PanNickel databases, the predicted solvus temperatures are higher than our measurements as shown in Figure 2, but the predictions from PanNickel show smaller differences compared to the experimentally determined values.
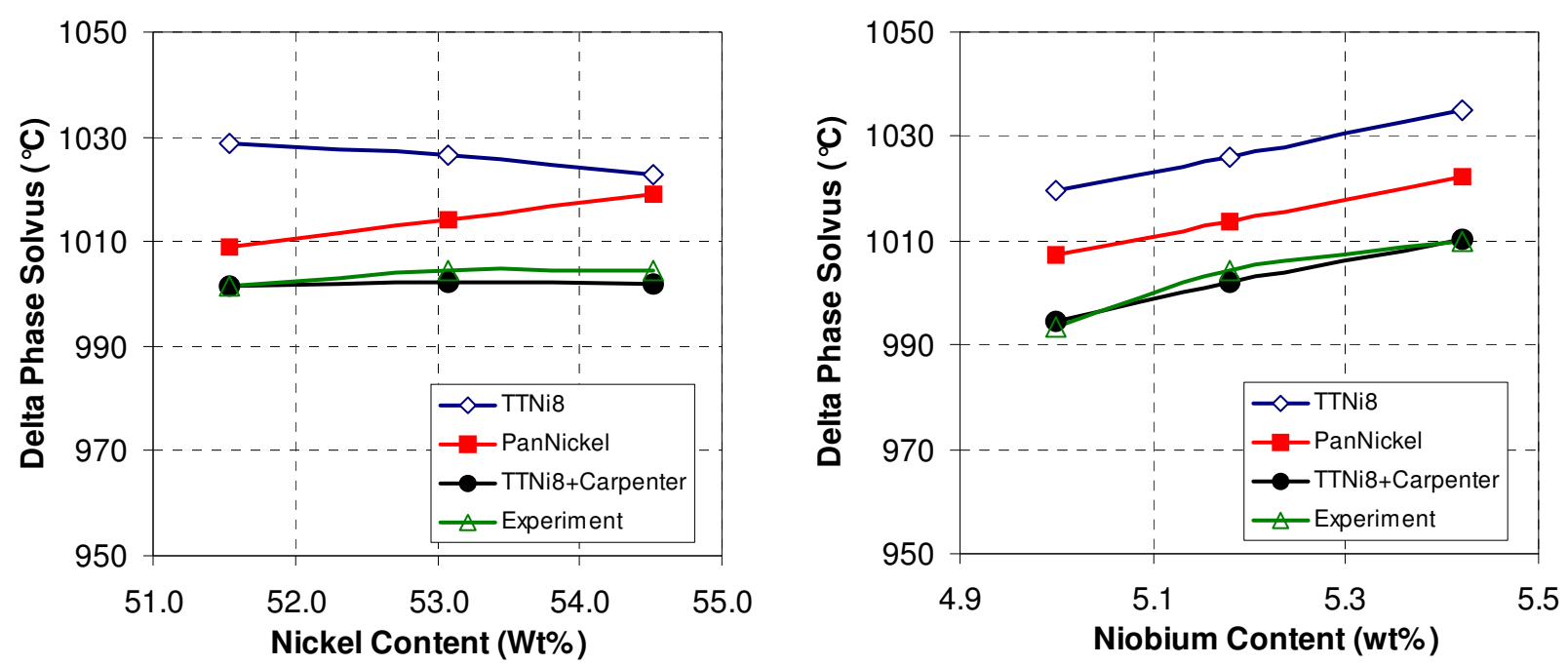

Figure 2. Effect of nickel and niobium contents on delta solvus temperature of alloy 718 - comparison of modeling predictions and experimental results.

PanNickel also predicted that the delta phase solvus temperature increases with nickel concentration, while Ni-DATA (TTNi8) shows the opposite tendency. In terms of the effect of niobium, both databases predict that the delta phase solvus temperature increases with niobium concentration, which agrees with the experimental measurements.

Further studies showed that the disagreement between the predictions and experimental measurements originates from the deficiency of the database in describing the solubilities of niobium in the FCC phase for $\mathrm{Ni}-\mathrm{Cr}-\mathrm{Nb}$ and $\mathrm{Ni}-\mathrm{Fe}-\mathrm{Nb}$ ternary systems. A new database (Carpenter) was developed for the two ternary systems, and much better agreement was achieved by appending the database to the Ni-DATA (TTNi8) database in the thermodynamic calculations (shown as TTNi8+Carpenter in Figure 2).

\section{Mechanical Properties}

Figure 3 shows the effect of solution treatment temperature on hardness of alloy 718 with variations in nickel and niobium content. There is no significant effect of nickel content on solution annealing response but, as would be expected, hardness and recrystallization temperature increased with niobium content in the 5.0-5.4\% range.

The room-temperature mechanical property data for both treatments are tabulated in Table IV and compositional effects are illustrated in Figures 4 and 5. 


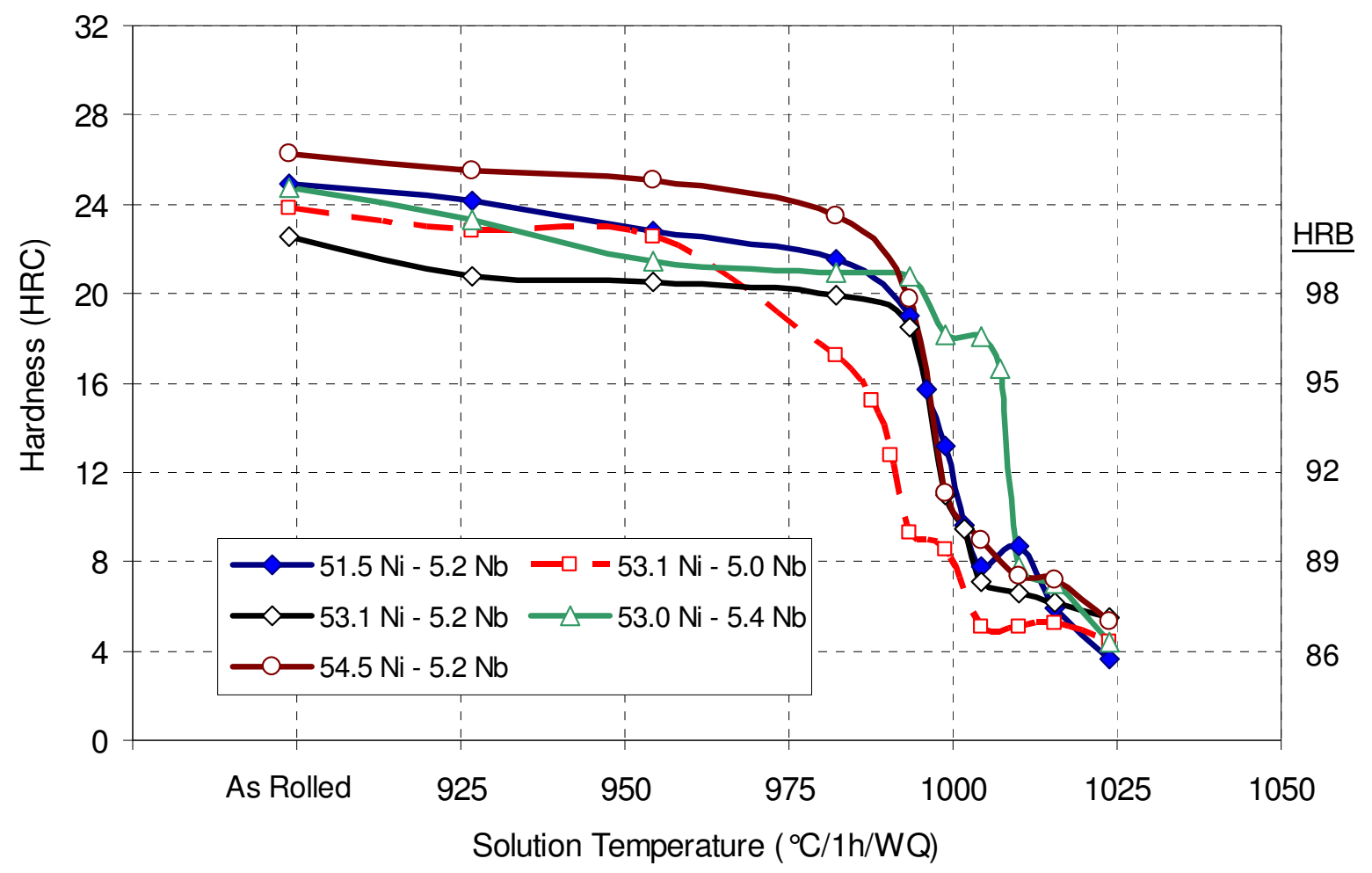

Figure 3. Effect of solution treatment temperature on hardness of alloy 718 with variations in nickel and niobium contents

Table IV. Room-Temperature Mechanical Properties of Alloy 718 With Variations in Nickel and Niobium Contents

\begin{tabular}{|c|c|c|c|c|c|c|c|c|c|c|c|c|c|}
\hline & \multicolumn{6}{|c|}{$\begin{array}{c}\text { Aerospace Heat Treatment } \\
954^{\circ} \mathrm{C} / 1 \mathrm{~h} / \mathrm{AC}+718^{\circ} \mathrm{C} / 8 \mathrm{~h} / \mathrm{FC} \text { to } 621^{\circ} \mathrm{C} / 8 \mathrm{~h} / \mathrm{AC}\end{array}$} & \multicolumn{6}{|c|}{$\begin{array}{c}\text { Oil-Field Heat Treatment } \\
1024^{\circ} \mathrm{C} / 1 \mathrm{~h} / \mathrm{OQ}+785^{\circ} \mathrm{C} / 6 \mathrm{~h} / \mathrm{AC} \\
\end{array}$} \\
\hline & & \multicolumn{4}{|c|}{ Room-Temperature Tensile } & \multirow[b]{2}{*}{ Hardness } & \multirow{2}{*}{\begin{tabular}{|c|} 
CVN \\
Impact \\
\end{tabular}} & \multicolumn{4}{|c|}{ Room-Temperature Tensile } & \multirow{3}{*}{$\frac{\text { Hardness }}{\text { HRC }}$} & \multirow{2}{*}{$\frac{\mathrm{CVN}}{\text { Impact }}$} \\
\hline $\mathrm{Ni}$ & $\mathrm{Nb}$ & $0.2 \% \mathrm{YS}$ & UTS & Elong. & RA & & & $0.2 \% \mathrm{YS}$ & UTS & Elong. & RA & & \\
\hline (wt\%) & (wt\%) & (MPa) & (MPa) & (\%-4D) & (\%) & HRC & (J) & (MPa) & (MPa) & $(\%-4 D)$ & (\%) & & (J) \\
\hline 51.5 & 5.2 & 1249 & 1486 & 18 & 32 & 46 & 22 & 901 & 1264 & 27 & 46 & 38 & 100 \\
\hline$"$ & $"$ & 1250 & 1486 & 19 & 34 & & 23 & 875 & 1255 & 28 & 48 & & 103 \\
\hline 53.1 & 5.0 & 1229 & 1471 & 19 & 37 & 45 & 33 & 810 & 1219 & 30 & 51 & 38 & 111 \\
\hline$"$ & $"$ & 1222 & 1471 & 19 & 36 & & 34 & 816 & 1216 & 30 & 50 & & 114 \\
\hline 53.1 & 5.2 & 1224 & 1464 & 18 & 32 & 45 & 30 & 894 & 1251 & 27 & 47 & 39 & 103 \\
\hline " & " & 1230 & 1465 & 18 & 34 & & 28 & 880 & 1242 & 29 & 53 & & 104 \\
\hline 53.0 & 5.4 & 1238 & 1484 & 19 & 32 & 46 & 24 & 892 & 1261 & 29 & 51 & 39 & 101 \\
\hline " & $"$ & 1231 & 1483 & 19 & 39 & & 23 & 899 & 1262 & 29 & 49 & & 102 \\
\hline 54.5 & 5.2 & 1228 & 1490 & 18 & 31 & 46 & 25 & 870 & 1256 & 30 & 52 & 38 & 107 \\
\hline$"$ & " & 1225 & 1489 & 18 & 29 & & 26 & 870 & 1253 & 29 & 50 & & 108 \\
\hline
\end{tabular}




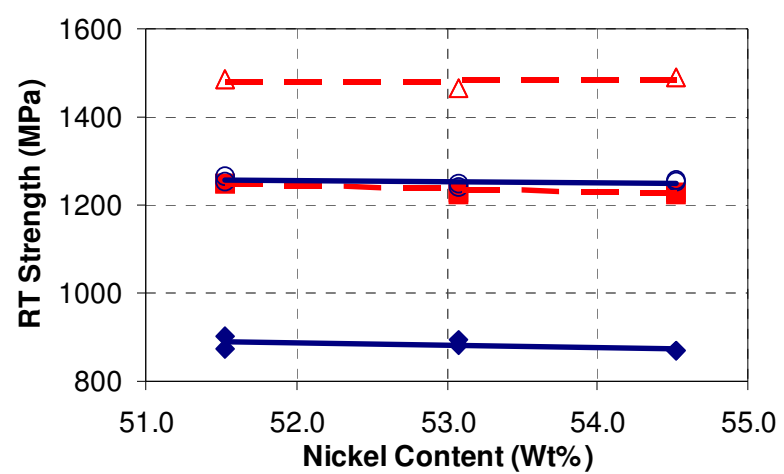

$\square$ Aero HT YS $\triangle$ Aero HT UTS $\diamond$ Oil-Field HT YS O Oil-Field HT UTS

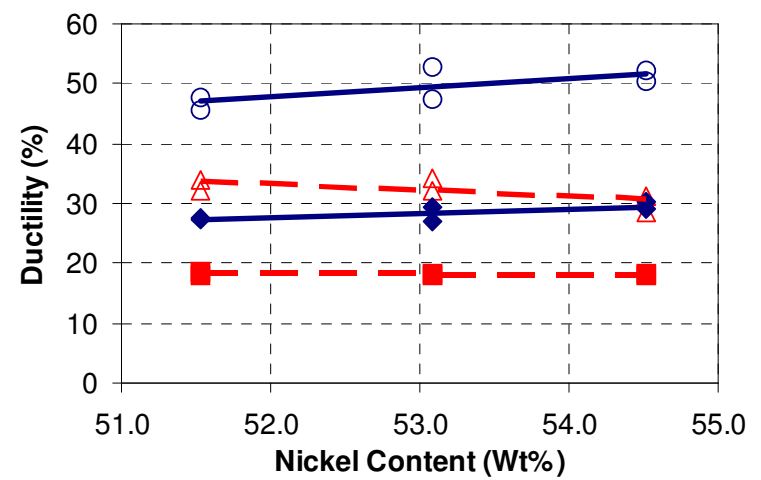

$\square$ Aero HT Elong $\triangle$ Aero HT RA $\bullet$ Oil-Field HT Elong O Oil-Field HT RA

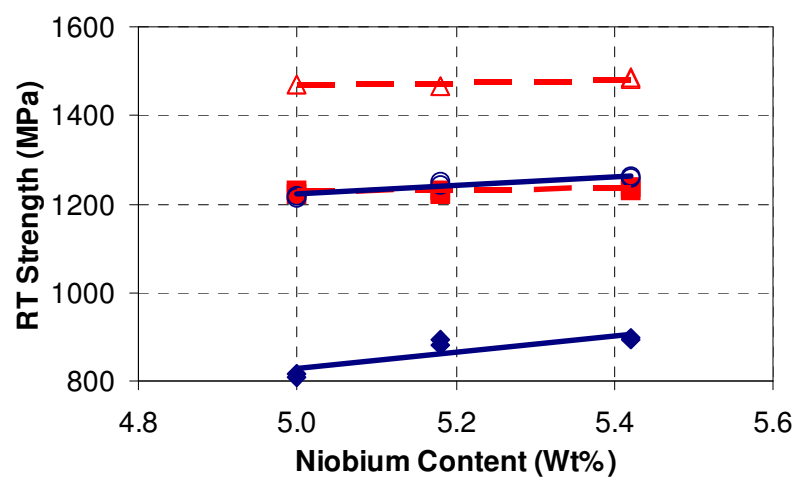

$\square$ Aero HT YS $\triangle$ Aero HT UTS $\diamond$ Oil-Field HT YS O Oil-Field HT UTS

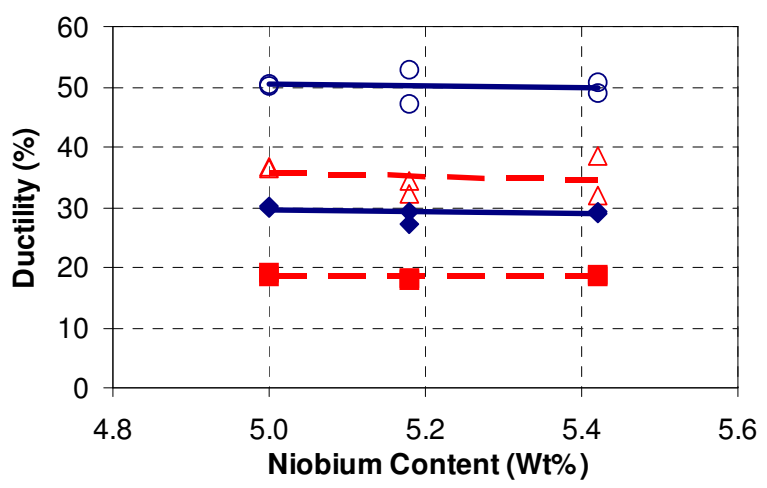

$\square$ Aero HT Elong $\triangle$ Aero HT RA $\bullet$ Oil-Field HT Elong O Oil-Field HT RA

Figure 4. Effect of nickel and niobium contents on room-temp. tensile properties of alloy 718

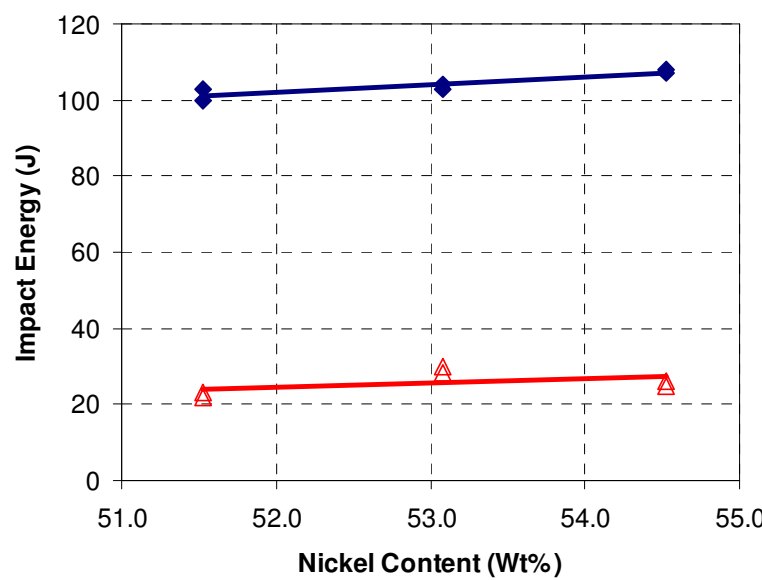

$\triangle$ Aerospace Heat Treatment $\bullet$ Oil-Field Heat Treatment

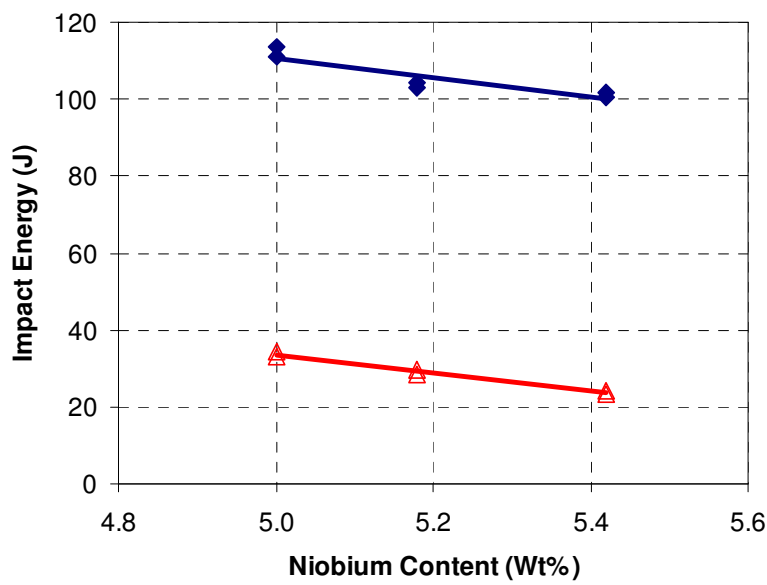

$\triangle$ Aerospace Heat Treatment $\bullet$ Oil-Field Heat Treatment

Figure 5. Effect of nickel and niobium contents on Charpy v-notch impact toughness of alloy 718 
For both heat treatments, nickel content within the range of 51.5-54.5\% had little or no effect on room-temperature tensile properties and possibly a slightly beneficial effect on impact toughness. Niobium within the range of 5.0-5.4\% increased strength and reduced toughness. Note that the oil-field heat treatment produced toughness values 3-5 times higher than the aerospace heat treatment. The higher toughness is attributed to lower strength/higher ductility but also to the absence of delta phase in grain boundaries. Delta phase is essential for creep-rupture notch ductility of alloy 718 at high temperatures but can reduce impact and fracture toughness at lower temperatures.

Stress-rupture test results are tabulated in Table V and compositional effects are illustrated in Figure 6. Neither element had significant effects on stress-rupture properties within the ranges evaluated.

Table V. Room-Temperature Mechanical Properties of Alloy 718 With Variations in Nickel and Niobium Contents

\begin{tabular}{|c|c|c|c|c|}
\hline \multicolumn{2}{|c|}{} & \multicolumn{3}{|c|}{ Aerospace Heat Treatment } \\
\cline { 3 - 5 } \multicolumn{2}{|c|}{} & $954^{\circ} \mathrm{C} / 1 \mathrm{~h} / \mathrm{AC}+718^{\circ} \mathrm{C} / 8 \mathrm{~h} /$ FC to $621^{\circ} \mathrm{C} / 8 \mathrm{~h} / \mathrm{AC}$ \\
\cline { 3 - 5 } & \multicolumn{3}{|c|}{ Stress-Rupture $\left(649{ }^{\circ} \mathrm{C} / 758 \mathrm{MPa}\right)$} \\
\hline Nickel & Niobium & Life & Elong. & RA \\
\hline (wt\%) & (wt\%) & (hours) & $(\%-4 \mathrm{D})$ & $(\%)$ \\
\hline 51.5 & 5.2 & 59 & 27 & 63 \\
\hline$"$ & $"$ & 55 & 28 & 62 \\
\hline 53.1 & 5.0 & 68 & 27 & 63 \\
\hline$"$ & $"$ & 80 & 27 & 64 \\
\hline 53.1 & 5.2 & 80 & 25 & 61 \\
\hline$"$ & $"$ & 83 & 28 & 62 \\
\hline 53.0 & 5.4 & 75 & 27 & 63 \\
\hline$"$ & $"$ & 62 & 26 & 62 \\
\hline 54.5 & 5.2 & 45 & 26 & 62 \\
\hline$"$ & $"$ & 45 & 28 & 60 \\
\hline
\end{tabular}



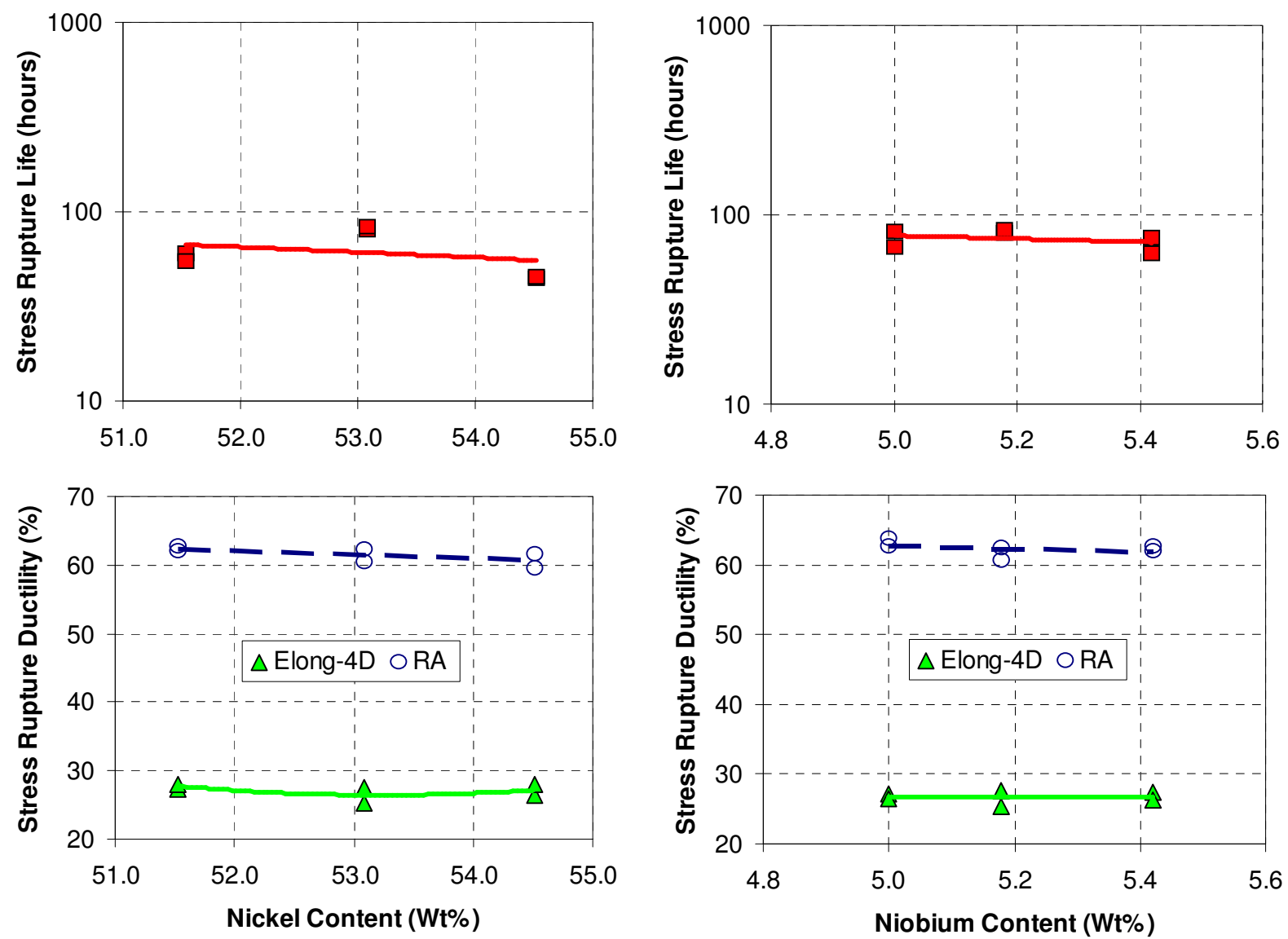

Figure 6. Effect of nickel and niobium contents on stress-rupture properties of alloy 718

\section{Conclusions}

This research, supported by prior investigations, shows that nickel content in alloy 718 does not influence the solvus temperature of the delta and gamma double prime phases. Nickel content within the range of 51.5-54.5\% also had no significant effect on mechanical properties after heat treatment to aerospace or oil-field specifications. Secondary Laves phase was observed in lower nickel $(51.5 \%)$ material exposed at $925^{\circ} \mathrm{C} / 1700^{\circ} \mathrm{F}$ (not present with $53.1 \% \mathrm{Ni}$ ), which confirms that there is a minimum critical nickel content, when replaced with iron, to ensure a Laves-free microstructure even in wrought product that was homogenized at the ingot stage. Higher niobium contents did produce the expected effects of higher solvus temperature, higher hardness/strength, and lower ductility/toughness. The oil-field super-solvus solution treatment plus overage heat treatment produces lower strength but higher ductility and toughness compared to the aerospace sub-solvus plus double-age treatment. A newly-developed thermodynamic database resulted in an improvement in the prediction of delta solvus temperature by appending to the Ni-DATA database in the thermodynamic calculations. 


\section{Acknowledgements}

The authors would like to thank Fan Zhang of CompuTherm for providing Pandat ${ }^{\circledR} 8.0$ software and PanNickel database for the thermodynamic calculations. In addition, the authors acknowledge Trevor Clark of Penn State University for assistance with electron microscopy.

\section{References}

1. N.A. Wilkinson, "Forging of 718 - Importance of T.M.P.," Superalloy 718-Metallurgy and Applications, ed. E. A. Loria, TMS, 1989, 119-133.

2. J.F. Radavich, "The Physical Metallurgy of Cast and Wrought Alloy 718," Superalloy 718Metallurgy and Applications, ed. E. A. Loria, TMS, 1989, 229-240.

3. R.E. Schafrik, D.D. Ward, and J.R. Groh, "Application of Alloy 718 in GE Aircraft Engines: Past, Present and Next Five Years," Superalloys 718, 625, and Various Derivatives, ed. E. A. Loria, TMS, 2001, 1-11.

4. E.L. Raymond, "Effect of Chemistry and Processing on the Structure and Mechanical Properties of Inconel Alloy 718," Superalloys 718, 625, and Various Derivatives, ed. E. A. Loria, TMS, 1989, 577-587.

5. J.R. Groh and J.F. Radavich, "Effects of Iron, Nickel, and Cobalt on Precipitation Hardening of Alloy 718," Superalloys 718, 625, and Various Derivatives, ed. E. A. Loria, TMS, 1991, 351361.

6. W.D. Cao, "Solidification And Solid State Phase Transformation Of Allvac ${ }^{\circledR}$ 718Plus $®$ Alloy," Superalloys 718, 625, and Various Derivatives, ed. E. A. Loria, TMS, 2005, 165-177.

7. N. Saunders, M. Fahrmann and C.J. Small, "The Application of CALPHAD Calculations to Ni-Based Superalloys," Superalloys 2000, eds. K.A. Green, T.M. Pollock and R.D. Kissinger, TMS, 2000, 803-811.

8. http://www.computherm.com/databases.html, CompuTherm LLC, 2008.

9. J.-C. Zhao and M.F. Henry, "The Thermodynamic Prediction of Phase Stability in MultiComponent Superalloys," JOM, 54 (1) (2002), 37-41.

10. G.B. Olson, H.-J. Jou, J. Jung, J.T. Sebastian, A. Misra, I. Locci, and D. Hull, "Precipitation Model Validation in $3^{\text {rd }}$ Generation Aeroturbine Disc Alloys," Superalloys 2008, ed. R.C Reed et al, TMS, 2008, 923-932.

11. L. Yang, K. Chang, S. Mannan, and J. DeBarbadillo, "A New DTA Approach for Verifying Precipitate Solvus in Inconel Alloy 718," Superalloys 718, 625, 706, and Various Derivatives, ed. E. A. Loria, TMS, 1997, 353-365.

12. N.B. Dahotre, M.H. McCay, T.D. McCay, C.R. Hubbard, W.D. Porter, and O.B. Cavin, "Effect of Grain Structure on Phase Transformation Events in the Inconel 718," Scripta Metallurgica et Materialia, 28 (11) (1993), 1359-1364. 
13. M.J. Cieslak, G.A. Knorovsky, T.J. Headley and AD. Romig Jr., "Solidification Metallurgy of Alloy 718 and Other Nb-containing Superalloys," Superalloy 718-Metallurgy and Applications, ed. E. A. Loria, TMS, 1989, 59-68.

14. G.K. Bouse, "Application of a Modified Phase Diagram to the Production of Cast Alloy 718 Components," Superalloy 718-Metallurgy and Applications, ed. E. A. Loria, TMS, 1989, 69-78. 